var. los, Strecker.

var. perdita, Dyar.

var. quadriguttatus, Grote.

semiauratus, Neumoegen and Dyar.

S. THULE, Strecker.

S. auratus, Grote.

Dr. Strecker objects to the reference of quadriguttatus as a variery of argenteomaculatus, and would consider it a distinct species; but I am unable to find a good specific character. I should hesitate to rely on the colour alone in this genus, and have preferred to follow Prof. Smith's "List."

Harrison G. Dyar.

ALEXICLES ASPERSA, Grote.

As pointed out by Prof. Smith, the original description of Alexicles is entirely inadequate. In fact, no characters are given which will determine its family position, the author going as far as to partially retract his own opinion as to its location. I have before me the type, very kindly forwarded to me for examination by Mr. W. A. Snow. It is a true Arctian apparently most nearly allied to Leptarctia. Head moderately prominent, tongue imperceptible; median spurs of hind tibir wanting; anterior tibia armed at tip with a stout, slightly curved spine or claw. of frenulum a long spine, hooked into a loop on subcostal vein of primaries. Venation arctiiform; one internal vein on primaries, two on secondaries; median veins four-branched, normal; cells closed; vein 8 of secondaries from the subcostal more than one-third the length of cell from base. On primaries no accessory cell ; veins 7-10 stalked; 8 and 9 forming a short furcation near apex of wing; 7 nearer the furcation and Io rather near the cell, leaving a long stalk between their origins; vein I I from the subcostal near end of cell; vein 12 from the base half way between the subcostal vein and costa.

Fore-wings narrow, costa straight, apex rounded; hind-wings oval.

It is scarcely necessary to add anything to Mr. Grote's description of the species. Though short, it is excellent, as are nearly all of Mr. Grote's specific descriptions. Mr. Grote gives the expanse as $32 \mathrm{~mm}$.; but in the type, mounted as usual, the wings reach $3^{6} \mathrm{~mm}$.

Harrison G. Dyar.

\title{
DR. HAGEN,
}

We deeply regret the loss of our old friend, Dr. Hermann August Hagen, Professor of Entomology in Harvard University, who died, after a long illness, at Cambridge, Mass., on the $9^{\text {th }}$ of November, in the seventy-seventh year of his age. 